\title{
Utiecai toplinske modifikacije bukovine na čvrstoću dužinski spojenih tokarenih elemenata metodom rotacijskog zavarivania
}

\section{Influence of Thermal Modification of Beech on the Strength of Longitudinally Connected Turned Elements by Rotational Welding Method}

\author{
Izvorni znanstveni rad $\bullet$ Original scientific paper \\ Prispjelo-received: 20. 10. 2010. \\ Prihvaćeno-accepted: 25. 2. 2011. \\ UDK: $630 * 824 ; 674.028 .1$ \\ doi:10.5552/drind.2011.1034
}

\begin{abstract}
SAŽETAK • Tehnika rotacijskog zavarivanja drva noviji je način spajanja drvenih dijelova bez upotrebe ljepila, uz pomoć topline koja nastaje trenjem elemenata koje spajamo. Tijekom procesa zavarivanja zbog utjecaja tlaka i topline rastali se površinski sloj drva (lignin i drvne polioze) koji je u međusobnom kontaktu. Istraživanje se temelji na ispitivanju utjecaja toplinske modifikacije i vode (sobne temperature) na čvrstoću zavarenog spoja. Ispitni su uzorci bili dužinski spojeni tokareni elementi izrađeni od bukovine. Toplinski modificirano drvo može se uspješno zavarivati. Rezultati istraživanja pokazali su da se s porastom temperature toplinske modifikacije $i$ potapanjem uzoraka u hladnu vodu $\left(20^{\circ} \mathrm{C}\right)$ izvlačna sila, odnosno čvrstoća spoja smanjuje s porastom gubitka mase pri termičkoj modifikaciji smanjuje se izvlačna sila. U uzoraka koji su bili izloženi utjecaju vode najveća je čvrstoća spoja zabilježena pri zavarivanju drva modificiranoga na $140{ }^{\circ} \mathrm{C}$, a najmanja pri zavarivanju drva modificiranoga na $180^{\circ} \mathrm{C}$.
\end{abstract}

Ključne riječi: bukovina, zavarivanje masivnoga i modificiranog drva, čvrstoća zavarenog spoja, dužinsko spajanje

\begin{abstract}
Wood welding technique is a newer way of connecting wooden parts without using glue with the temperature usually achieved by friction of elements that are connected. During the welding process, due to the influence of pressure and temperature, the surface wood layer (lignin and polyoses) is melted. The research is based on an examination of the influence of thermal modification and the impact of water (room temperature) on the strength of welded joints. Test samples were longitudinally connected turned elements made of solid beech wood. Thermally modified wood can be successfully welded. The results showed that increasing the temperature
\end{abstract}

Autori su viši asistent, student i profesor na Šumarskom fakultetu Sveučilišta u Zagrebu, Zagreb, Republika Hrvatska.

Authors are senior assistant, student and professor at Faculty of Forestry, University of Zagreb, Croatia. 
of thermal modification and immersing the samples in cold water $\left(20^{\circ} \mathrm{C}\right)$ cause the decrease of embedded force and tensile strength, respectively. The research has also shown that the increase in weight loss during thermal modification reduces the tensile forces. With samples immersed in cold water, the highest joint strength was recorded in welding thermally modified wood at $140{ }^{\circ} \mathrm{C}$ and the lowest joint strength was recorded in welding thermally modified wood at $180^{\circ} \mathrm{C}$.

Key words: beech, welding of solid and modified wood, strength of welded joints, longitudinal bonding

\section{UVOD}

\section{INTRODUCTION}

Zavarivanje drva trenjem proces je u kojemu se zbivaju kemijsko-fizikalne reakcije, zbog trenja nastaje toplina koja tali i omekša strukturu drva, a hlađenjem tako nastale taline dobiva se čvrsti spoj. Metodom zavarivanja mogu se uspješno spojiti dva ili više elemenata drva bez dodavanja bilo kakvog ljepila ili vezivnog sredstava. Na površinama koje se dodiruju zbog trenja se pojavljuje povišena temperatura koja omekša i rastali strukturu drva (lignin i hemicelulozu) te nataju kemijske promjene. Kemijske promjene počinju s početkom zavarivanja i traju i nakon prestanka zavarivanja (u fazi skrućivanja taline). Hlađenjem struktura drva otvrdnjava te čini čvrsti spoj. Kemijske promjene koje nastaju u drvu nisu obuhvaćene ovim istraživanjem, već su primijenjena znanja iz dostupne literature.

Modifikacija drva postiže se djelovanjem kemijskih, bioloških ili fizikalnih činitelja na drvo, a rezultat tog djelovanja jest promjena kemijskog sastava s ciljem poboljšanja određenih osobina (Hill, 2006). Kombiniranjem vrste grijućeg medija, vremena trajanja procesa, završne temperatura te vrste drva koja će biti modificirana (glavnih parametara modifikacije), dobivaju se željena svojstva modificiranog drva. Promjenom kemizma stanične stijenke smanjuje se njezin afinitet prema vodi, što dovodi do poboljšavanja dimenzionalne stabilnosti. Smanjenjem veličina bubrenja i utezanja smanjuju se naprezanja u sustavu premaz površina drva te se produljuje vijek trajanja drva, ali i proizvoda izrađenih od modificiranog drva (Hasan i Despot, 2008).

Prema istraživanjima Živkovića i dr. (2008), dobiveno je veliko smanjenje točke zasićenosti vlakanaca (prosječno za $15 \%$ ) i sobnoga ravnotežnog sadržaja vode (prosječno za 3,5 do $5 \%$ ) pregrijanog drva u odnosu prema prirodnome. Ti se podaci odnose na jasenovinu i bukovinu obrađenu na dvije temperaturne razine, na 190 i $210^{\circ} \mathrm{C}$. Koeficijenti utezanja pregrijanog drva nisu smanjeni u usporedbi s nemodificiranim, ali je apsolutno smanjenje vodoupojnosti za $50 \%$ rezultiralo povećanjem dimenzijske stabilnosti za $60 \%$. Toplinska obrada drva pridonosi manjoj vodoupojnosti, poboljšava dimenzijsku stabilnost, povećava otpornost drva prema biološkoj razgradnji. Takvom se drvu smanjuju mehanička svojstva, promjena boje (zbog modifikacije) na suncu nije stalna i modificirano drvo širi miris paljevine u prostor (Jirouš-Rajković i dr., 2007).

Mehanička svojstva termički modificiranog drva smanjuju se u smjeru vlakanaca drva i okomito na njih. Na temelju ispitivanja čvrstoće modificiranog drva na udarac mogu se procijeniti njegova mehanička svojstva (Rapp i Sailer, 2001). Čvrstoća modificiranog drva na udarac linearno se smanjuje s porastom temperature modifikacije. Čvrstoća na udarac termički modificiranog drva manja je za $60 \%$ u odnosu prema netretiranom drvu (Sinn i dr., 2002). Ako je modifikacija provedena u zraku, čvrstoća na udarac bit će znatno manja nego pri modifikaciji provedenoj u dušiku. Windeisen i dr. (2007) ispitivali su kemijske promjene na bukovini tijekom termičke modifikacije. Rezultati istraživanja pokazali su da toplinska obrada bukovine na različitim temperaturama uzrokuje promjenu tehnoloških obilježja drva. Postotak fenolnih $\mathrm{OH}$ grupa povećava se signifikantno s porastom temperature tretmana u usporedbi s neobrađenim drvom.

Jones i Pizzi (2007) istraživali su kako hladna i kipuća voda utječu na čvrstoću zavarenog spoja modificiranog drva sitkanske smreke. Rezultati istraživanja pokazali su veću izvlačnu silu spojeva toplinski i kemijski (na bazi alkohola) modificiranog drva za vrijeme izlaganja u kipućoj vodi (2 h). Nemodificirani uzorci imali su najveću izvlačnu silu u normalnim uvjetima, dok su kemijski modificirani uzorci (modificirani acetilacijskim sredstvom) imali najveću izvlačnu silu pri izlaganju u hladnoj vodi. Postupak zavarivanja modificiranog drva pokazao se primjenjivim i poboljšavao je čvrstoću spoja ako su zavareni spojevi bili izloženi utjecaju vlage i vode. Rezultati ispitivanja pokazuju da upotreba modificiranog drva pri zavarivanju može rezultirati spojem koji može izdržati veći utjecaj vlage. To otvara nove mogućnosti primjene postupka zavarivanja drva.

Utjecaj predgrijavanja drva i presjeka na linearno vibracijsko zavarivanje istraživali su Omrani i dr. (2009). Rezultati istraživanja pokazali su da predgrijavanje površine prije zavarivanja u bukovine pridonosi povećanju posmične čvrstoće s povećanjem predgrijavanja, dok je u hrastovine s povećanjem predgrijavanja zabilježen pad posmične čvrstoće te se povećava standardna devijacija izvlačne sile.

Župčić i dr. (2009) istraživali su zavarivanje moždanika u podlogu od toplinski tretirane i netretirane grabovine. Temperatura toplinske modifikacije iznosila je $200{ }^{\circ} \mathrm{C}$ u trajanju $48 \mathrm{~h}$. Frekvencija vrtnje bukova moždanika iznosila je $1520 \mathrm{okr}$./min. Istraživanje je pokazalo da moždanici zavareni u podlogu od grabovine koja nije bila toplinski modificirana imaju veću izvlačnu silu (prosječno $84 \%$, što je statistički značajna razlika) nego moždanici zavareni u toplinski modificiranu podlogu.

Provedeno je istraživanje (Župčić, 2010) u kojemu je moždanik (toplinski modificiran i nemodificiran) zavarivan u smjeru vlakanaca i okomito na njih u po- 
Tablica 1. Uzorci korišteni u istraživanju

Table 1 Research samples

\begin{tabular}{|c|l|}
\hline $\begin{array}{c}\text { Oznaka } \\
\text { Code }\end{array}$ & Opis / Description \\
\hline $\mathrm{N}$ & uzorci netretirani toplinski / Normal test samples \\
\hline $\mathrm{T} 14$ & uzorci tretirani toplinski, na temperaturi $140{ }^{\circ} \mathrm{C} /$ Test samples thermally modified at $140{ }^{\circ} \mathrm{C}$ \\
\hline $\mathrm{T} 16$ & uzorci tretirani toplinski, na temperaturi $160{ }^{\circ} \mathrm{C} /$ Test samples thermally modified at $160^{\circ} \mathrm{C}$ \\
\hline $\mathrm{T} 18$ & uzorci tretirani toplinski, na temperaturi $180{ }^{\circ} \mathrm{C} /$ Test samples thermally modified at $180{ }^{\circ} \mathrm{C}$ \\
\hline $\mathrm{NV}$ & uzorci netretirani toplinski, potapani u hladnu vodu / Normal test samples immersed in cold water \\
\hline $\mathrm{TV} 14$ & $\begin{array}{l}\text { uzorci tretirani toplinski, na temperaturi } 140{ }^{\circ} \mathrm{C} \text { i potapani u hladnu vodu } \\
\text { Test samples thermally modified at } 140{ }^{\circ} \mathrm{C} \text { and immersed in cold water }\end{array}$ \\
\hline $\mathrm{TV} 16$ & $\begin{array}{l}\text { uzorci tretirani toplinski, na temperaturi } 160^{\circ} \mathrm{C} \text { i potapani u hladnu vodu } \\
\text { Test samples thermally modified at } 160^{\circ} \mathrm{C} \text { and immersed in cold water }\end{array}$ \\
\hline $\mathrm{TV} 18$ & $\begin{array}{l}\text { uzorci tretirani toplinski, na temperaturi } 180{ }^{\circ} \mathrm{C} \text { i potapani u hladnu vodu } \\
\text { Test samples thermally modified at } 180^{\circ} \mathrm{C} \text { and immersed in cold water }\end{array}$ \\
\hline
\end{tabular}

dlogu koja nije bila modificirana, te u podlogu koja je bila modificirana (toplinski i kemijski limunskom kiselinom). Zador pri zavarivanju iznosio je $1,6 \mathrm{~mm}$, frekvencija vrtnje $1520 \mathrm{okr} / \mathrm{min}$, uz trajanje procesa zavarivanja $0,8 \mathrm{~s}$. Usporedbom zavarivanja moždanika u modificiranu bukovinu toplim zrakom i u nemodificiranu bukovinu u smjeru vlakanaca te okomito na njih, uočena je statistički značajna razlika u veličini izvlačne sile. I pri lijepljenju nažlijebljenog moždanika u modificiranu bukovinu toplim zrakom i u nemodificiranu bukovinu pokazala se statistički značajna razlika. Modifikacija bukovine toplim zrakom i limunskom kiselinom utječe na smanjenje (statistički značajno) izvlačne sile zavarenoga ili lijepljenog spoja. Pri zavarivanju moždanika modificiranoga limunskom kiselinom i toplim zrakom u nemodificiranu podlogu izvlačna se sila odnosno čvrstoća spoja ne može izmjeriti jer je vlačna čvrstoća moždanika smanjena, te se moždanik lomi na vlak (prosječna sila pri kojoj nastaje lom modificiranog moždanika jest $2586 \mathrm{~N}$ ).

Toplinskom se modifikacijom smanjuju mehanička svojstva drva, ali se poboljšava njegova dimenzijska stabilnost te mu se smanjuje ravnotežni sadržaj vode. Ta pozitivna fizikalna svojstva nastojala su se iskoristiti za eventualno povećanje čvrstoće spoja u uzoraka izloženih utjecaju vode. Stoga je cilj rada bio istražiti utjecaj režima toplinske modifikacije bukovine i hladne vode na čvrstoću odnosno izvlačnu silu zavarenog spoja kod dužinski spojenih tokarenih elemenata. Istraživanje utjecaja hladne vode na čvrstoću spoja provedeno je prema normi za ljepilo (HRN EN 204). Osim spomenutih čimbenika, istraživan je i utjecaj početne gustoće drva i gubitka mase zbog toplinske modifikacije na čvrstoću spoja.

\section{MATERIJALI I METODE 2 MATERIALS AND METHODS}

\subsection{Izrada uzoraka zavarivanjem 2.1 Welding of samples}

Istraživanja utjecaja toplinske modifikacije bukovine i hladne vode na čvrstoću dužinski spojenih tokarenih elemenata provedena su na Šumarskom fakultetu Sveučilišta u Zagrebu. Od ukupno 200 zavarenih uzoraka (modificiranih i nemodificiranih), 193 su uključena $\mathrm{u}$ istraživanja, a sedam je uzoraka za vrijeme zavarivanja raspucalo, pa nisu korišteni u daljnjim razmatranjima. Za dužinsko sastavljanje tokarenih elemenata upotrijebljeni su uzorci bukovine promjera $30 \mathrm{~mm}$. Duljina uzoraka iznosila je $160 \mathrm{~mm}$, uvećana za duljinu glatkoga tokarenog čepa koja je iznosila $20 \mathrm{~mm}$. Promjer rupe bio je $8,50 \mathrm{~mm}$, a prosječni promjer čepa 9,92 mm (prosječni zador iznosio je 1,42 mm). Zavarivanje čepa u rupu vršeno je u kontroliranim uvjetima, uz pomoć posebno prilagođenog uređaja i pristroja. Broj okretaja pri zavarivanju uzoraka bio je konstantan i iznosio je $1520 \mathrm{okr}$./min, a prosječno trajanje zavarivanja iznosilo je $0,96 \mathrm{~s}$, što odgovara pomaku čepa od $0,82 \mathrm{~mm}$ po okretaju. Nakon prestanka rotacije zadržan je pritisak na spojene elemente u trajanju od dvije do četiri sekunde. Skice toplinski modificiranih i nemodificiranih uzoraka korištenih u ovom istraživanju prikazane su na slikama 1. i 2, a presjek dužinski spojenih (zavarenih) tokarenih elemenata prikazan je na slici 3.
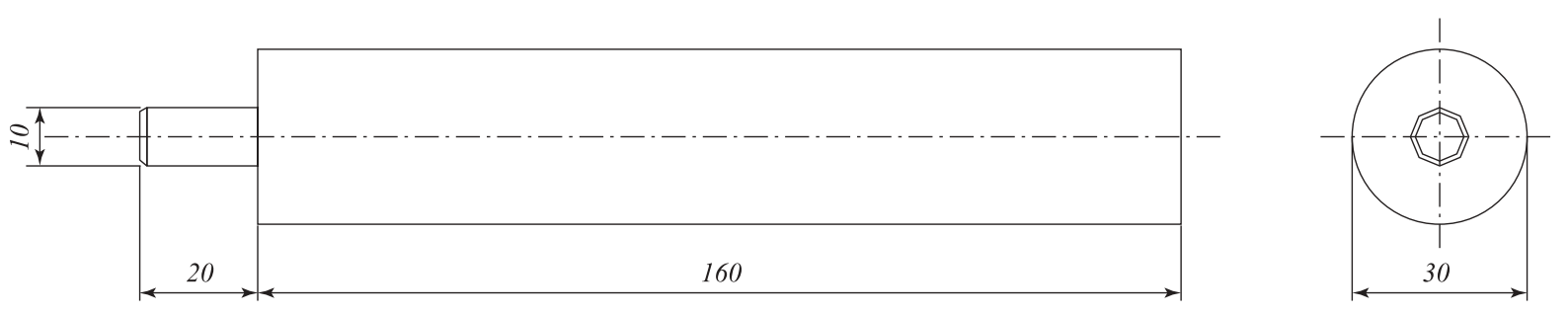

Slika 1. Tokareni ispitni uzorak s čepom duljine $20 \mathrm{~mm}$

Figure 1 Turned test sample with dowel length of $20 \mathrm{~mm}$ 

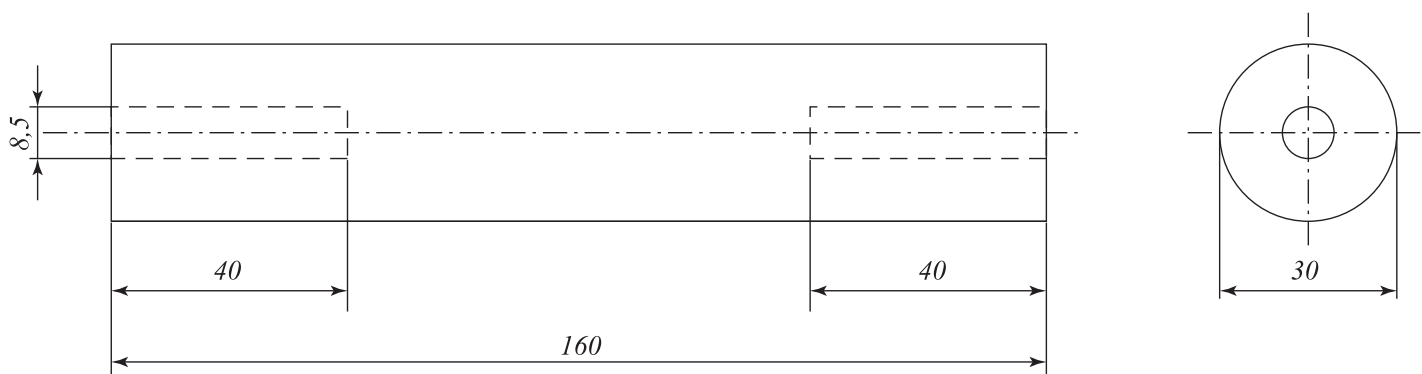

Slika 2. Tokareni ispitni uzorak s rupom promjera $8,5 \mathrm{~mm}$

Figure 2 Turned test sample with a hole of $8.5 \mathrm{~mm}$ in diameter

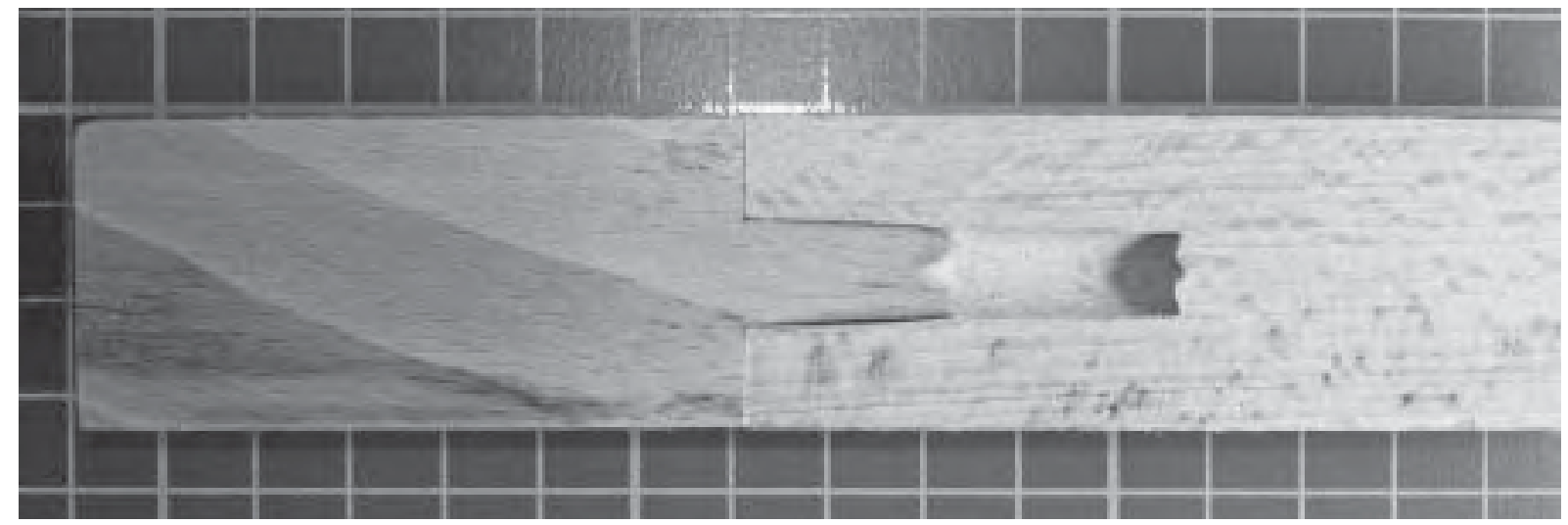

Slika 3. Uzdužni presjek tokarenog elementa dužinski spojenoga uz pomoć čepa duljine $20 \mathrm{~mm}$

Figure 3 Cross section of linearly turned beech element with a $20 \mathrm{~mm}$ dowel

\subsection{Određivanje sadržaja vode i gustoće}

2.2 Determination of moisture content and density

Sadržaj vode određivao se prema HRN ISO 3130:1999 (hrvatska norma za određivanje sadržaja vode za ispitivanje fizikalnih i mehaničkih svojstava drva). Prosječan sadržaj vode nakon sušenja uzoraka $\left(103 \pm 2{ }^{\circ} \mathrm{C}\right.$ ) iznosio je 9,40\% (min. 8,81\%, maks. $10,08 \%)$.

Nakon što je određen sadržaj vode u drvu, na istim je probama određivana gustoća drva prema HRN ISO 3131:1999 (hrvatska norma za određivanje gustoće drva za ispitivanje fizikalnih i mehaničkih svojstava drva). Prosječna gustoća bukovine iznosila je $0,71 \mathrm{~g} /$ $\mathrm{cm}^{3}$ (min. 0,67 g/ $\mathrm{cm}^{3}$, maks. 0,77 g/ $\mathrm{cm}^{3}$ ).

\subsection{Postupak toplinske modifikacije bukovine \\ 2.3 Process of thermal modification of beech}

Postupak toplinske modifikacije bukovine proveden je prije zavarivanja uzoraka. Uzorci su toplinski modificirani na temperaturama 140,160 i $180{ }^{\circ} \mathrm{C}$. Postupak toplinske modifikacije uzoraka sastojao se od sušenja uzoraka na temperaturi $103 \pm 2{ }^{\circ} \mathrm{C}$ do $0 \%$ sadržaja vode. Nakon određivanja mase vaganjem uzorci su zagrijani na temperaturu od $140,160 \mathrm{i} 180^{\circ} \mathrm{C}$ (ovisno o vrsti ispitivanja) u trajanju od $9 \mathrm{~h}$. Trajanje zagrijavanja sušionika od $103 \pm 2{ }^{\circ} \mathrm{C}$ do željene temperature iznosilo je oko $30 \mathrm{~min}$, isto koliko i postupno smanjivanje temperature na $103 \pm 2{ }^{\circ} \mathrm{C}$. Nakon toplinske modifikacije uzorcima je određena masa vaganjem kako bi se mogao odrediti gubitak mase nakon modifikacije. Prije zavarivanja uzorci su kondicionirani $\mathrm{u}$ laboratorijskim uvjetima (temperatura $23 \pm 2{ }^{\circ} \mathrm{C}$, relativna vlaga zraka $50 \pm 5 \%$ u trajanju tri tjedna.
Prosječni sadržaj vode (nakon kondicioniranja) uzoraka tretiranih na $140{ }^{\circ} \mathrm{C}$ iznosio je $5,73 \%$, tretiranih na $160{ }^{\circ} \mathrm{C}$ iznosio je $4,43 \%$ a tretiranih na $180{ }^{\circ} \mathrm{C}$ iznosio je $1,56 \%$.

\subsection{Postupak potapanja uzoraka u hladnu vodu \\ 2.4 Procedure of immersing samples in cold water}

Nakon toplinske modifikacije, kondicioniranja u laboratorijskim uvjetima (temperatura $23 \pm 2{ }^{\circ} \mathrm{C}$, relativna vlaga zraka $50 \pm 5 \%$ ) i zavarivanja, polovica uzoraka potapana je u hladnu vodu. Ispitivanje se provodilo prema normi za ljepila HRN EN 204. Uzorci su bili potapani u vodi pri $20 \pm 5^{\circ} \mathrm{C}$, u vremenu od $3 \mathrm{~h}$. Nakon potapanja višak vode uklonjen je suhom krpom i uzorci su ostavljeni dva dana na kondicioniranju u laboratorijskim uvjetima (temperatura $23 \pm 2{ }^{\circ} \mathrm{C}$, relativna vlaga zraka $50 \pm 5 \%$ ). Nakon kondicioniranja uzorcima je određena masa vaganjem i potom su stavljeni na sušenje. Postupak se sastojao od postupnog zagrijavanja uzoraka na temperaturu $103 \pm 2{ }^{\circ} \mathrm{C}$ do $0 \%$ sadržaja vode. Nakon sušenja uzorci su tri tjedna kondicionirani u laboratorijskim uvjetima, te im je prosječni sadržaj vode za modifikaciju na $140{ }^{\circ} \mathrm{C}$ iznosio $4,15 \%$, za $160{ }^{\circ} \mathrm{C}$ sadržaj vode je bio $3,81 \%$, a uzorci modificirani na $180{ }^{\circ} \mathrm{C}$ imali su prosječni sadržaj vode od 2,38 \%.

\subsection{Metoda ispitivanja}

2.5 Test method

Ispitivanje rotacijski zavarenih spojeva (moždanika) na toplinski modificiranim i u hladnu vodu potapanih bukovih uzoraka provedeno je na univerzalnoj kidalici u Zavodu za znanost o drvu na Šumarskom fakultetu Sveučilišta u Zagrebu. Pomak za vrijeme ispiti- 
vanja iznosio je $5 \mathrm{~mm} / \mathrm{min}$. Uz pomoć računala obavljena su mjerenja sile i pomaka, pa su sve vrijednosti točno i precizno izmjerene.

\section{REZULTATI I DISKUSIJA}

\section{RESULTS AND DISCUSSION}

\subsection{Utjecaj toplinske modifikacije bukovine i hladne vode na izvlačnu silu}

3.1 Influence of thermal modification of beech and cold water on embedded force

Rezultati istraživanja (tabl. 2 i sl. 4) pokazali su da toplinska modifikacija bukovine, a pogotovo hladna voda, imaju negativan utjecaj na izvlačnu silu odnosno na čvrstoću spoja. Najbolje rezultate izvlačne sile postigli su nemodificirani uzorci, što je bilo i očekivano. Što je temperatura modifikacije, veća to je čvrstoća spoja odnosno izvlačna sila manja. Drvu se modifikacijom povećava krtost, pa dolazi do loma vlakanaca, a ne do isprepletanja u talini, što je rezultiralo smanjenjem izvlačne sile zavarenog čepa. Smanjenje mehaničkih svojstava u smjeru vlakanaca i okomito na njih, slabljenje otpornosti na cijepanje te znatan porast krtosti posljedica su termičke modifikacije (Feist i dr., 1987; Rapp i Sailer, 2001). Pri zagrijavanju drva bez kisika najprije se razgrađuju drvne polioze (hemiceluloze), zatim celuloza, te na kraju lignin (Tjeerdsma i dr., 1998). Upravo je ta razgradnja celuloze jedan od čimbenika koji utječu na čvrstoću zavarenog spoja.

Potapanjem nemodificiranih i modificiranih uzoraka u hladnu vodu rezultiralo je značajnijim smanjenjem izvlačne sile. Toplinski netretirani uzorci koji su potapani u hladnu vodu (NV) imaju u prosjeku $47 \%$ manju izvlačnu silu od uzoraka netretiranih toplinski i nepotapanih u hladnu vodu $(\mathrm{N})$. Uzorci tretirani toplinski na temperaturi $140{ }^{\circ} \mathrm{C}$ potapani u hladnu vodu (TV14) imaju u prosjeku $41 \%$ manju izvlačnu silu od nepotapanih uzoraka (T14). Uzorci tretirani toplinski na temperaturi $160{ }^{\circ} \mathrm{C}$ potapani u hladnu vodu (uzorci TV16) imaju u prosjeku $50 \%$ manju izvlačnu silu od uzoraka tretiranih na temperaturi $160{ }^{\circ} \mathrm{C}$ koji nisu bili potapani u hladnu vodu (T16). Uzorci tretirani toplinski na temperaturi $180{ }^{\circ} \mathrm{C}$ potapani u hladnu vodu (TV18) imaju u prosjeku $42 \%$ manju izvlačnu silu od uzoraka koji nisu potapani (T18). Dobiveni rezultati imaju sličan trend kao i rezultati do kojih su u svojim istraživanjima došli Jones i Pizzi (2007). Iz njihova istraživanja također je vidljiv negativan utjecaj hladne vode na izvlačnu silu.

Prema rezultatima istraživanja, za gotovo sve spojeve koji su izloženi utjecaju hladne vode zamijećen je pad izvlačne sile, samo je pri toplinskoj modifikaciji na $140{ }^{\circ} \mathrm{C}$ zabilježen porast izvlačne sile u usporedbi s nemodificiranim drvom. Stoga se može zaključiti da nije opravdana upotreba toplinske modifikacije jer daje vrlo malo poboljšane rezultate od zavarivanja drva koje nije bilo toplinski modificirano. Osim toga, sam proces podrazumijeva određenu potrošnju energije i vremena, a dobiveni rezultati nisu značajno bolji. S obzirom na to da se toplinskom modifikacijom povećava dimenzijska stabilnost drva, pretpostavljeno je da će zavareni spoj od modificiranog drva biti otporniji na utjecaj vode. Rezultati istraživanje nisu potvrdili tu pretpostavku.

$\mathrm{U}$ ovom je istraživanju odabran zador od 1,42 mm, koji nipošto nije optimalan jer je prema Pizziju i dr. (2003) zador od 2 mm optimalan, a ako je veći ili manji, izvlačna se sila smanjuje (primijenjena frekvencija vrtnje iznosila je $1200 \mathrm{okr}$./min). U istraživanju je korišten manji zador od optimalnoga da bi se spriječilo raspucavanje modificiranog drva. Modifikacijom se povećava krtost drva, što dovodi do pojave pukotina u zavarenom spoju i time se smanjuje čvrstoća spoja. Svaki spoj na kojem se pojavi pukotina ne može se rabiti u daljnjim istraživanjima. Prema provedenim istraŽivanjima (Župčić i dr., 2010), vidljivo je da izvlačna sila postiže maksimalne iznose pri zadoru od 2 do 2,5 $\mathrm{mm}$, pa su to ujedno i optimalni zadori za rotacijsko zavarivanje nažlijebljenih moždanika (frekvencija vrtnje $1520 \mathrm{okr} . / \mathrm{min}$ ). Kada se zadori povećavaju ili smanjuju u odnosu prema optimalnima, dolazi do smanjenja izvlačne sile odnosno čvrstoće spoja (odnosi se na toplinski neobrađeno drvo).

Tablica 2. Deskriptivna statistika izvlačne sile u ovisnosti o toplinskoj modifikaciji bukovine i o hladnoj vodi

Table 2 Descriptive statistics of results of embedded force in dependence on thermal modification of beech and cold water

\begin{tabular}{|l|c|c|c|c|c|c|c|c|}
\hline $\begin{array}{c}\text { Oznaka } \\
\text { uzorka } \\
\text { Code }\end{array}$ & $\begin{array}{c}\text { Aritmetička } \\
\text { sredina } \\
\text { izvlačne sile } \\
\text { Embedded } \\
\text { force } \\
\text { Means } \\
\mathrm{N}\end{array}$ & $\begin{array}{c}\text { Broj } \\
\text { uzoraka } \\
\text { Number of } \\
\text { samples }\end{array}$ & $\begin{array}{c}\text { Standardna } \\
\text { devijacija } \\
\text { izvlačne sile } \\
\text { Embedded force } \\
\text { Std. Dev. }\end{array}$ & $\begin{array}{c}\text { Minim. } \\
\text { izvlačna sila } \\
\text { Embedded } \\
\text { force } \\
\text { Minimum }\end{array}$ & $\begin{array}{c}\text { Maks. } \\
\text { izvlačna sila } \\
\text { Embedded } \\
\text { force } \\
\text { Maximum }\end{array}$ & $\begin{array}{c}\text { Izvlačna } \\
\text { sila Q25 } \\
\text { Embedded } \\
\text { force } \\
\text { Q25 }\end{array}$ & $\begin{array}{c}\text { Izvlačna } \\
\text { sila medijan } \\
\text { Embedded } \\
\text { force } \\
\text { Median }\end{array}$ & $\begin{array}{c}\text { Izvlačna } \\
\text { sila Q75 } \\
\text { Embedded } \\
\text { force) } \\
\text { Q75 }\end{array}$ \\
\hline N & 4616,0 & 25 & $\mathrm{~N}$ & $\mathrm{~N}$ & $\mathrm{~N}$ & $\mathrm{~N}$ & $\mathrm{~N}$ & $\mathrm{~N}$ \\
\hline T14 & 4318,0 & 25 & 798,7 & 2820,0 & 5660,0 & 4000,0 & 4260,0 & 4600,0 \\
\hline T16 & 3699,6 & 25 & 1020,2 & 1100,0 & 5610,0 & 3350,0 & 3680,0 & 4470,0 \\
\hline T18 & 2669,2 & 25 & 431,6 & 2080,0 & 3800,0 & 2340,0 & 2670,0 & 2780,0 \\
\hline NV & 2446,5 & 23 & 655,0 & 1020,0 & 3720,0 & 2130,0 & 2370,0 & 2750,0 \\
\hline TV14 & 2535,4 & 24 & 745,2 & 1050,0 & 4280,0 & 2060,0 & 2575,0 & 2990,0 \\
\hline TV16 & 1838,2 & 22 & 862,1 & 550,0 & 3680,0 & 1250,0 & 1790,0 & 2250,0 \\
\hline TV18 & 1541,8 & 22 & 427,7 & 820,0 & 2460,0 & 1150,0 & 1535,0 & 1750,0 \\
\hline Sve grupe & 3005,5 & 191 & 1289,1 & 550,0 & 6780,0 & 2130,0 & 2810,0 & 3980,0 \\
\hline
\end{tabular}




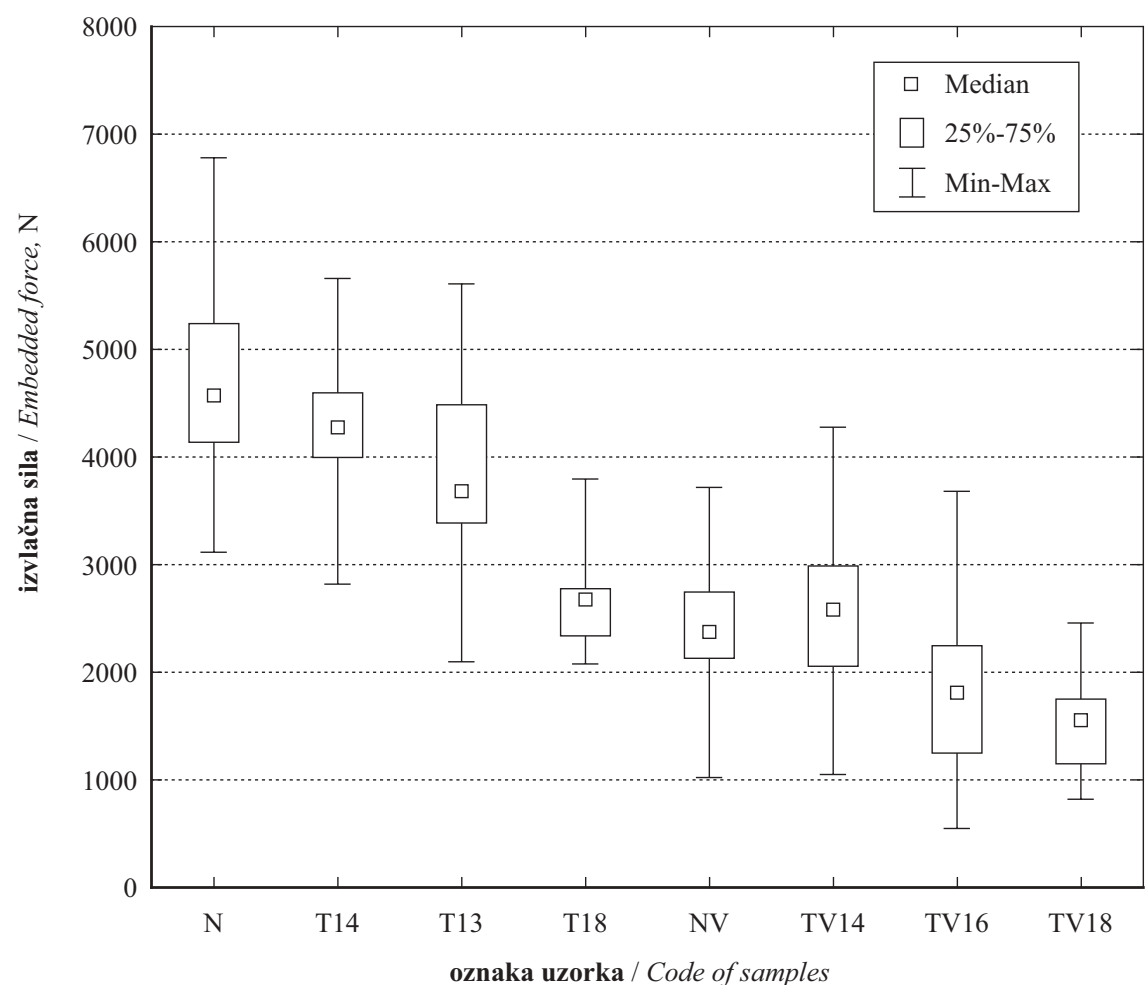

Slika 4. Utjecaj toplinske modifikacije bukovine i hladne vode na izvlačnu silu

Figure 4 Influence of thermal modification of beech and cold water on embedded force

3.2. Usporedba gubitka mase i izvlačne sile uzoraka tretiranih i netretiranih u hladnoj vodi

3.2 Comparison of mass loss and embedded force of treated and untreated samples in cold water

Rezultati istraživanja pokazali su da najmanji gubitak mase imaju uzorci koji su bili tretirani na temperaturi $140{ }^{\circ} \mathrm{C}$. Što je temperatura modifikacije bila veća, to je i gubitak mase veći, pa su najveći gubitak mase imali uzorci tretirani na temperaturi $180{ }^{\circ} \mathrm{C}$. Prosječni gubitak mase uzoraka tretiranih na $140{ }^{\circ} \mathrm{C}$ iznosio je 0,34 \% (min. 0,27, maks. 0,43\%). Za uzorke tretirane na $160{ }^{\circ} \mathrm{C}$ gubitak mase iznosio je $0,85 \%$ (min. 0,57, maks. 1,43\%), dok je gubitak mase uzoraka tretiranih na $180{ }^{\circ} \mathrm{C}$ iznosio $3,09 \%$ (min. 1,80 , maks. 5,53\%). Na slici 5. prikazan je utjecaj gubitka mase na izvlačnu silu. Vidljivo je da se porastom gubi-

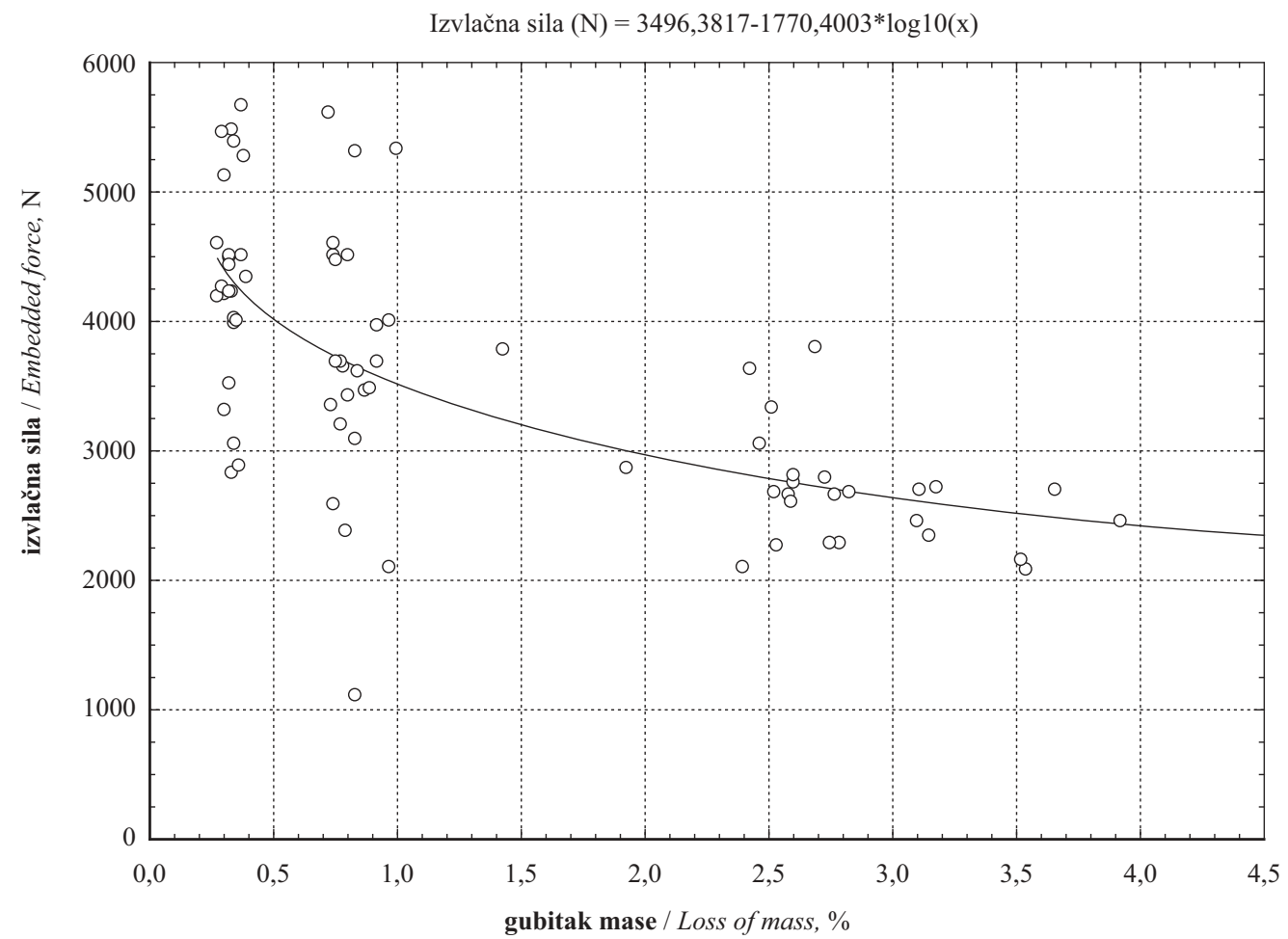

Slika 5. Utjecaj gubitka mase na izvlačnu silu u toplinski tretiranih uzoraka

Figure 5 Influence of mass loss on embedded force of thermally treated samples 


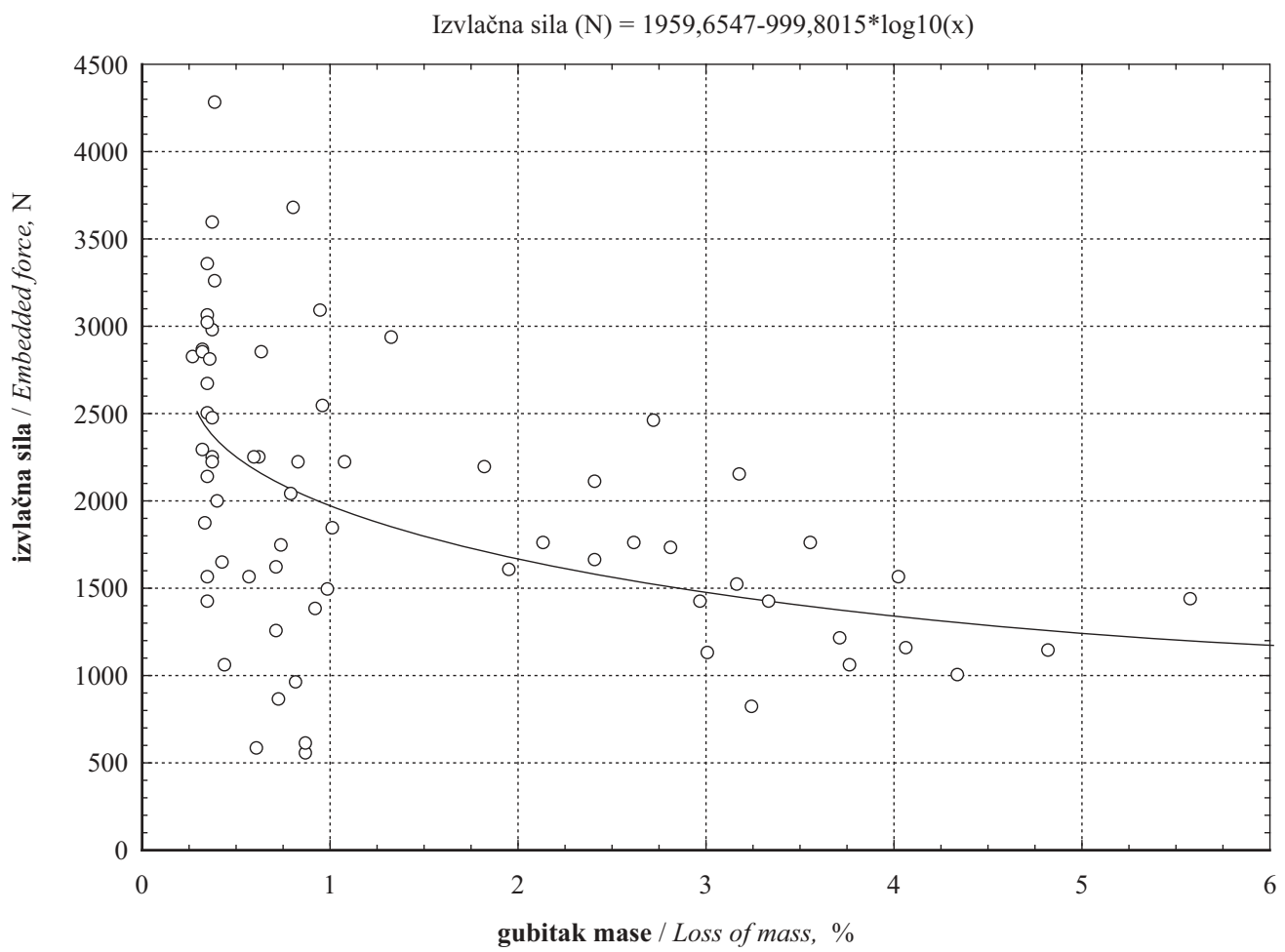

Slika 6. Utjecaj gubitka mase na izvlačnu silu u toplinski tretiranih uzoraka potapanih u hladnu vodu Figure 6 Influence of mass loss on embedded force of thermally treated samples immersed in cold water

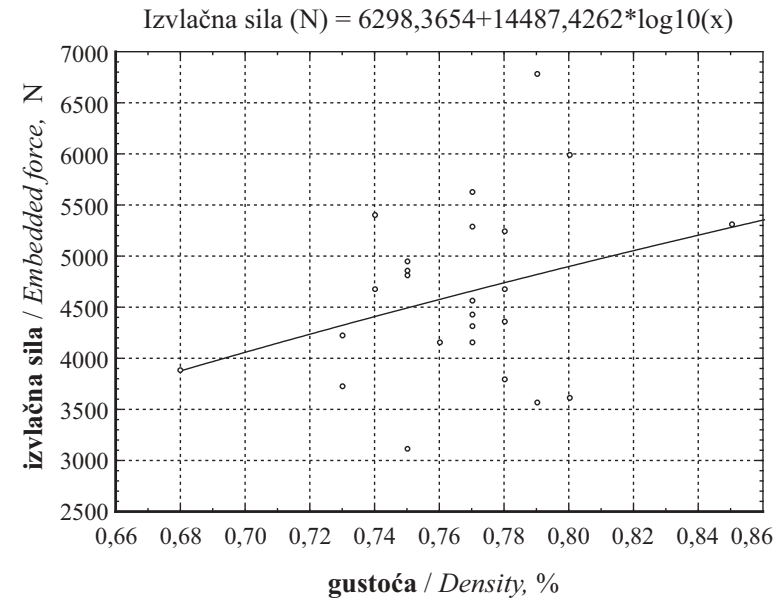

a) $\mathrm{N}$

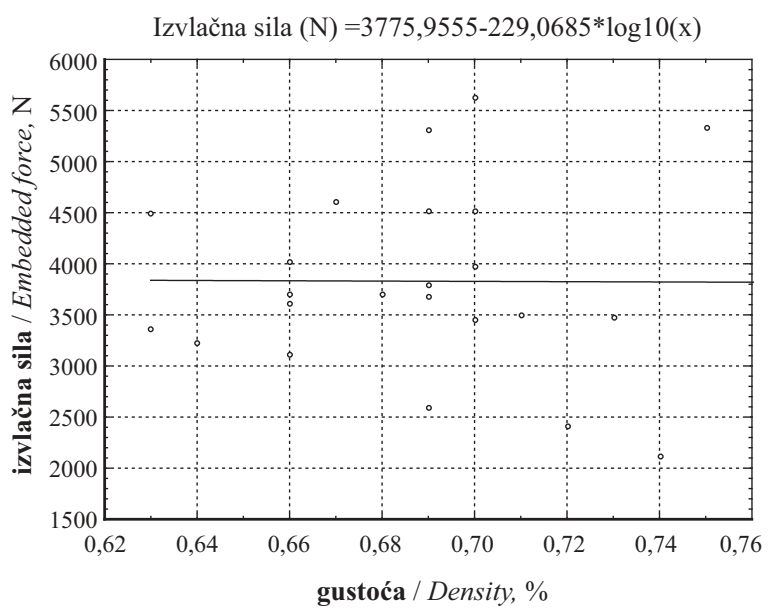

c) T16

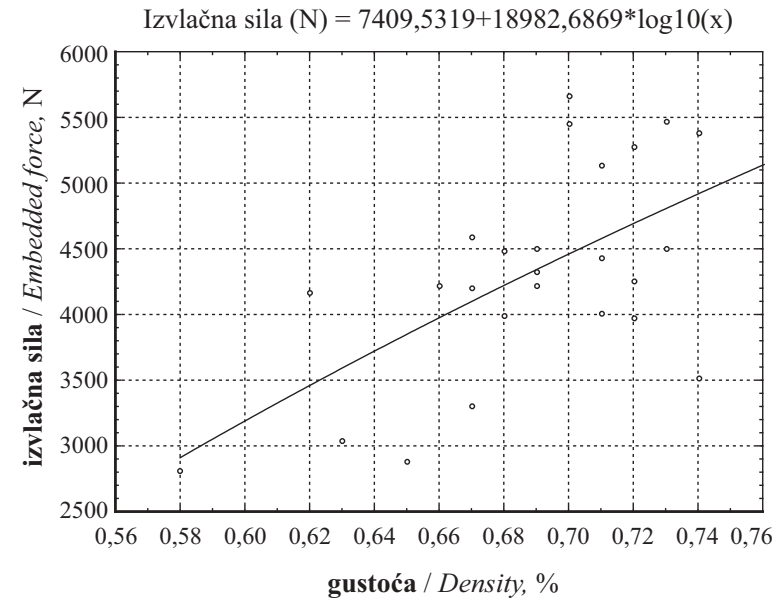

b) T14

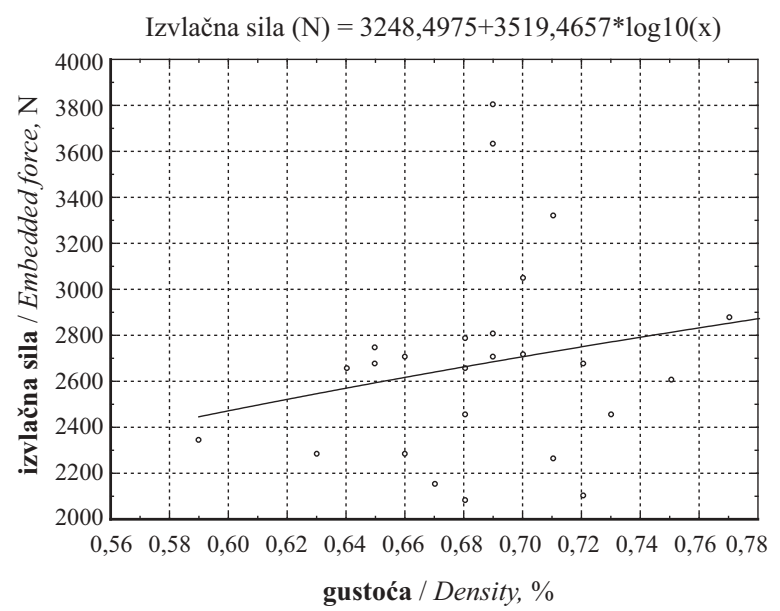

d) T18

Slika 7. a), b), c), d) Utjecaj gustoće na izvlačnu silu u uzoraka netretiranih hladnom vodom Figure $7 \mathbf{a}, \mathbf{b}, \mathbf{c}, \mathbf{d}$ Influence of density on embedded force of untreated samples in cold water 


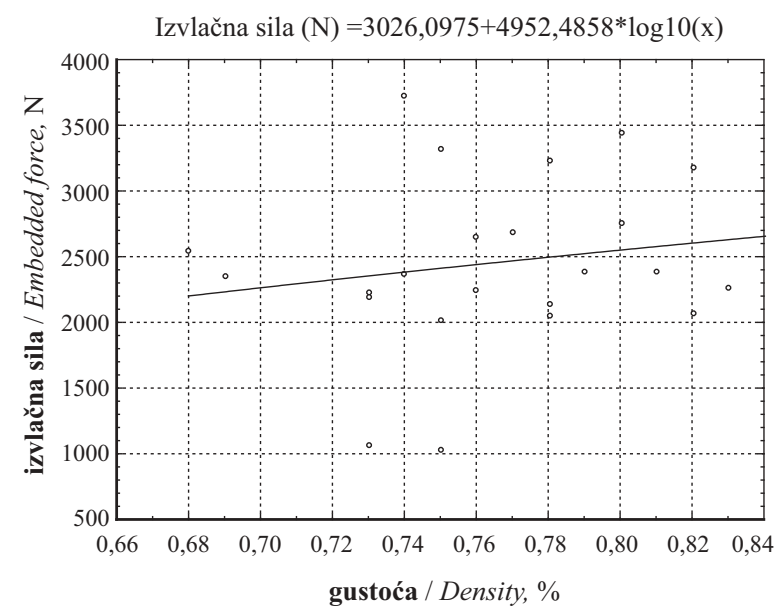

a) $\mathrm{N}$

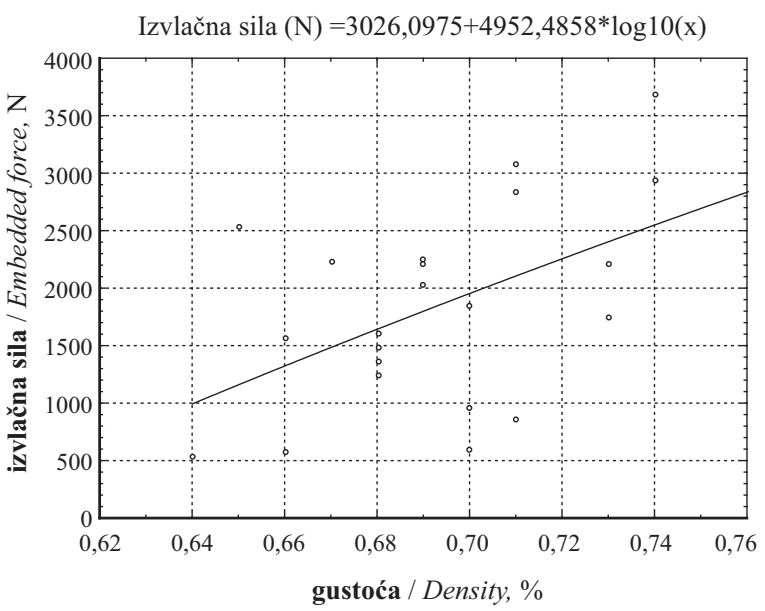

c) T16

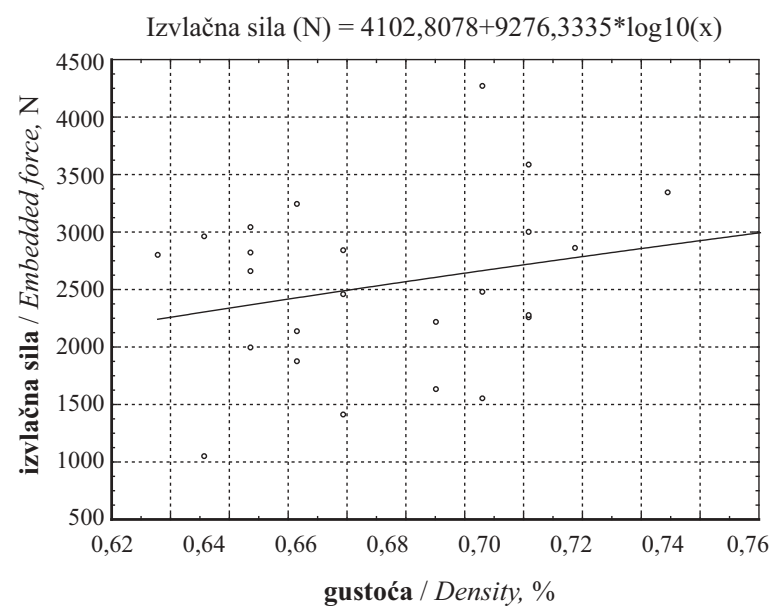

b) T14

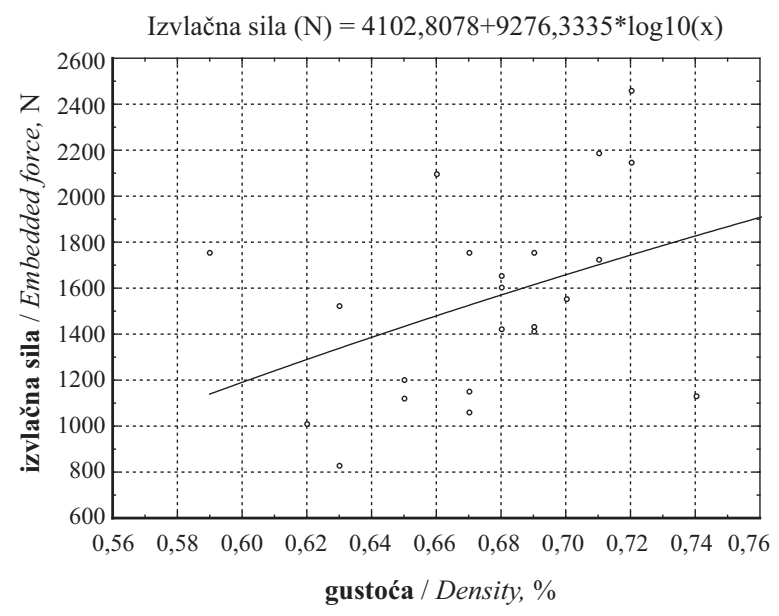

d) T18

Slika 8. a), b), c), d) Utjecaj gustoće na izvlačnu silu u uzoraka tretiranih hladnom vodom

Figure 8 a, b, c, d. Influence of density on embedded force of treated samples in cold water

tka mase (s povećanjem temperature modifikacije) smanjuje izvlačna sila zavarenih uzoraka. Povećanje temperature modifikacije dovodi do povećanja grešaka zavarivanja (pojavljuju se pukotine u elementima), što je negativno svojstvo modifikacije.

\subsection{Usporedba gustoće i izvlačne sile uzoraka} netretiranih i tretiranih u hladnoj vodi

3.3 Comparison of density and embedded force of untreated and treated samples in cold water

Razlike u anatomskoj i fizikalnoj građi drva svakako utječu na proces zavarivanja drva, pa se može pretpostaviti kako kemijska, anatomska i fizikalna svojstva unutar iste vrste drva imaju utjecaj na čvrstoću zavarenog spoja. Unutar iste širine goda postoje varijacije u udjelu ranoga i kasnog drva. Uz istu širinu goda veći udio kasnog drva (u bukovine) preduvjet je povećanja gustoće drva, što može utjecati na povećanje čvrstoće zavarenog spoja. Prema provedenim istraživanjima (Župčić, 2010), s porastom gustoće drva unutar ovog istraživanja porasla je izvlačna sila. Iz rezultata provedenog ispitivanja (sl. 7. i 8) vidljivo je da s povećanjem gustoće raste izvlačna sila toplinski tretiranih i netretiranih zavarenih uzoraka. Trend rasta izvlačne sile s porastom gustoće drva zabilježen je u uzoraka potapanih u hladnu vodu, ali i u uzoraka koji nisu tretirani hladnom vodom (sobne temperature).

\section{ZAKLJUČAK \\ 4 CONCLUSION}

Tokareni se elementi mogu uspješno dužinski spajati uz pomoć čepa tehnikom rotacijskog zavarivanja. Tako spojeni tokareni elementi mogli bi $\mathrm{u}$ budućnosti pronaći svoju primjenu u proizvodnji namještaja.

Toplinska modifikacija bukovine utječe na smanjenje izvlačne sile, odnosno čvrstoće zavarenog spoja. Najbolje rezultate izvlačne sile pokazuju uzorci koji nisu tretirani toplinski i nisu potapani u hladnu vodu (uzorci N). Eksperiment je pokazao da se s povećanjem temperature toplinske modifikacije vrijednosti izvlačne sile stalno smanjuju. Najlošije rezultate izvlačne sile imaju uzorci tretirani na temperaturi $180{ }^{\circ} \mathrm{C}$ (uzorci T18).

Hladna voda ima negativan utjecaj na toplinski modificirano, ali i na nemodificirano drvo (izvlačna sila u uzoraka potapanih u vodu prosječno se smanjuje od 40 do $50 \%$ ). U uzoraka potapanih u vodu najveću izvlačnu silu postigli su uzorci toplinski tretirani na $140{ }^{\circ} \mathrm{C}$, dok su nemodificirani uzorci imali statistički neznačajno manju izvlačnu silu. Za uzorke potapane u hladnu vodu bilo je očekivano da će pri svim primijenjenim temperaturama modifikacije izvlačna sila 
biti veća od one $u$ nemodificiranom drvu s obzirom na to da se modifikacijom povećava dimenzijska stabilnost drva, te mu se smanjuje afinitet prema vodi.

Istraživanje utjecaja gubitka mase na izvlačnu silu pokazalo je da se s porastom gubitka mase smanjuje izvlačna sila zavarenog spoja. S povećanjem temperature toplinske modifikacije raste gubitak mase uzoraka.

Eksperiment je pokazao da s porastom gustoće uzoraka raste izvlačna sila, odnosno čvrstoća zavarenog spoja.

\section{LITERATURA}

5 REFERENCES

1. Feist, W. C.; Sell, J., 1987: Weathering Behaviour of Dimensionally Stabilized Wood Treated by Heating under Pressure of Nitrogen Gas, Wood and Fiber Science, 19 (2):183-195.

2. Hasan, M.; Despot R., 2003: Termički modificirano drvo - materijal današnjice. Les - wood, 55 (3): 342-345.

3. Jirouš-Rajković, V.; Turkulin, H.; Živković, V., 2007: Metode poboljšanja svojstava građevnog drva. Drvna industrija, 58 (1): 23-33.

4. Jones, D.; Pizzi, A., 2007: Frictional welding of dowels into modified wood. Proceedings of the $5^{\text {th }}$ COST E34, Bonding of modified wood, September $6^{\text {th }}$ 2007., University of Ljubljana, Biotechnical Faculty, Bled-Slovenija, 13-19.

5. Leban, J.-M.; Mansouri, H. R.; Omrani, P.; Pizzi, A., 2008: Dependence of dowel welding on rotation rate. Holz Roh Werkst., (66): 241-242.

6. Omrani, P.; Mansouri, H. R.; Pizzi, A.; Masson, E., 2009: Influence of grain direction and pre-heating on linear wood welding. Eur. J. Wood Prod., 68 (1): 113-114. doi:10.1007/s00107-009-0349-6

7. Pizzi, A.; Properzi, M.; Leban, J.M.; Zanetti, M.; Pichelin, F., 2003: Mechanically - induced wood welding. Maderas. Cienca y tecnologia, 5 (2): 101 - 106.

8. Rapp, A. O.; Sailer, M., 2001: Oil-heat-treatment of wood - process and properties. Drvna industrija, 52 (2): 63-70.

9. Sinn, G.; Gindl, M.; Reiterer, A., 2002: Ausgewähtle materialphysikalische Eigenschaften von modifiziertem Holz. Modifiziertes Holz: Eigenschaften und Märkete, 171-189.
10. Tjeerdsma, B.; Boonstra, M.; Pizzi, A.; Tekely, P.; Militz, H., 1998: Two-steps heat-treated timber: molecular-level easons for wood perfomance improvement. Holz RohWerkstoff, 56 (3): 149-153.

doi: $10.1007 / \mathrm{s} 001070050287$

11. Windeisen, E.; Strobel, C.; Wegener, G., 2007: Chemical changes during the production of thermo-treated beech wood. Wood Sci Technol, 41: 523-536. doi:10.1007/s00226-007-0146-5

12. Živković, V.; Prša, I.; Turkulin, H.; Sinković, T., JiroušRajković, V., 2008: Dimensional stability of heat treated wood. Drvna industrija, 59 (2): 69-73.

13. Župčić, I.; Mihulja, G.; Govorčin, S.; Bogner, A.; Grbac, I.; Hrovat, B., 2009: Zavarivanje termički modificirane grabovine. Drvna industrija, 60 (3): 161-166.

14. Župčić, I., 2010: Čimbenici koji utječu na spajanje bukovih tokarenih elemenata tehnikom zavarivanja. Sveučilište u Zagrebu, Šumarski fakultet, disertacija, 1-237.

15. Župčić, I.; Bogner, A.; Grbac, I.; Lozančić, I., 2010: New insigts into rotation welding of beech wood. Proceedings of International conference: Wood is good - transferof knowledge in practice as a way out of the crisis: University of Zagreb, Faculty of Forestry, INNOVAWOOD, Zagreb, October $15^{\text {th }} 2010,147-152$.

16. ${ }^{* * *}$ HRN EN 204:2001 (klasifikacija termoplastičnih adheziva za drvo za nekonstrukcijske primjene).

17. *** HRN ISO 3130:1999 (hrvatska norma za određivanje sadržaja vode za ispitivanje fizikalnih i mehaničkih svojstava drva).

18. *** HRN ISO 3131:1999 (hrvatska norma za određivanje gustoće drva za ispitivanje fizikalnih i mehaničkih svojstava drva).

\section{Corresponding address:}

Assistant IVICA ŽUPČIĆ, Ph.D.

University of Zagreb

Faculty of Forestry

Svetošimunska 25, p.p. 422

HR-10002 Zagreb, Croatia

e-mail: izupcic@sumfak.hr 